\title{
Cholera Quarantine and Territorial Sovereignty in the Age of Imperialism: The Limits of Transnational Governance
}

\author{
Douglas Howland ${ }^{1}$ \\ ${ }^{1}$ Department of History, University of Wisconsin-Milwaukee, USA. \\ Correspondence: Douglas Howland, Department of History, University of Wisconsin-Milwaukee, USA.
}

Received: April 14, 2016

Accepted: May 20, 2016

Available online: May 23, 2016

doi:10.11114/ijsss.v4i6.1625

URL: http://dx.doi.org/10.11114/ijsss.v4i6.1625

\begin{abstract}
The movement to create an international policy for cholera quarantine in the nineteenth century necessarily engaged a set of transnational processes: the disease itself; world trade, which passed through the cholera zone of the Indian Ocean and Mediterranean Sea; and the growing territorialization of sovereignty, which raised questions of jurisdiction over ships and their crews and passengers in foreign ports. This essay examines the International Sanitary Conference as a transnational organization and a form of networked governance, as it attempted to establish an international quarantine policy between 1852 and 1892. At its 1881 meeting in Washington, DC, the US hosts attempted to move cholera policy forward by creating systems for the certification of the health of ships and the circulation of information regarding epidemic outbreaks. These efforts failed, and the 1881 meeting of the ISC reveals the limitations of networked governance in the nineteenth century, as collective and transnational policy initiatives ran aground against the growing assertion of exclusive state territory.
\end{abstract}

Keywords: cholera quarantine, International Sanitary Conference, international administrative law, networked governance, territorial sovereignty

\section{Introduction}

Three transnational processes of the nineteenth century inhabit this essay. First is disease, the cholera that was transferred among populations between the Indian Ocean and the length of the Mediterranean Sea, spreading as well into northern Europe and across the Atlantic and Pacific Oceans to the Americas and east Asia. Apart from the scholarly insight that disease is socially constructed, and the fact that the scientific construction of cholera remained inconclusive at the time, cholera in the nineteenth century represents a transnational process of particular sociopolitical force in terms of three factors that informed the trajectory of cholera: the growth of world trade and its passage of goods and people across the globe; the consolidation of the British empire, with sea passage routinized between India and Liverpool and every place along the way; and, of particular concern to the Mediterranean zone, the Hajj which drew Muslims from British India, north Africa, and the middle east to Mecca and back. War is of course a fourth factor, but it does not enter into our story. ${ }^{1}$

A second transnational process here is the development of international organizations in the nineteenth century and in particular the International Sanitary Conference (ISC). The ISC, which met eleven times between 1851 and 1903, worked to establish an international convention on cholera quarantine in order to streamline trade in the face of potential epidemics. International organizations such as the ISC present a particularly engaging form of transnational process and networked governance in that such organizations were not strictly committed to the sovereign state as a unit of membership. Rather, many were based in existing administrations and organized around practical concerns with technology such as the telegraph, uniform practices such as the post, standards such as weights and measures, or, in our case, the common threat of disease. The management of these concerns meant that non-sovereign entities such as colonies or protectorates were welcome to be members. Egypt, for example, because of its important position in the Mediterranean and, after 1869, because of the Suez Canal, participated in the ISC even as its status shifted from vassal

\footnotetext{
${ }^{1}$ There is a massive amount of material on cholera in the nineteenth century; useful points of departure include Bourdelais (1988); Hamlin (2009); McNeill (1976, pp. 261-280); and Pollitzer (1954).
} 
of the Ottoman Porte to British protectorate. That said, the ISC differed from other international organizations of the time such as the International Telegraph Union in that, first, the ISC never established a permanent administrative office, and second, the members restricted cooperation by insisting upon their exclusive rights over national territory. These points, I argue, help to account for both the dominance of the great powers within the ISC and the failure of the ISC to ratify any convention until the end of the nineteenth century. The ISC's successful Conventions of 1892 and 1894 were not so much a mark of transnational cooperation against cholera as evidence of a growing imperialism and a desire to police the business of shipping pilgrims to Mecca.

A third transnational process is the range of interstate or international relations that occurred around specific cases of quarantine. A recurring conflict in the nineteenth century was that between states opposed to quarantine in the interests of free trade, led by Britain and often France, and states or local port authorities who used quarantine as a method to curtail the spread of cholera, particularly those along the Mediterranean, including the Ottoman Empire, Egypt, the Two Sicilies, Sardinia, and Spain. Apart from the work of the ISC, states might also negotiate bilateral agreements over public health issues (see Martens, 1883-87, vol. II: p. 287f.). Embedded within these "international" relations were maritime commerce and the scientific misunderstanding of the etiology of cholera in the nineteenth century.

This essay accordingly hopes to illuminate persisting problems of international order and networked governance. International unions of the 19th century, such as the ISC, began to constitute an international order that, like the networks of global governance evolving in recent decades, reveals a diversity among the units of an international system. Both of these represent an inclusive international order unlike that of the 20th century, in which sovereign states were dominant (Howland, 2015). The current research of scholars such as Anne-Marie Slaughter (2004) or Benedict Kingsbury and colleagues (2005) reveals the extent to which multinational corporations, NGOs, and a variety of private organizations not only work alongside sovereign states today in a networked global order but begin to displace them. The global administrative network under formation today exhibits extensive inter-penetrations of not only national and international, but also public, corporate, and private agents, authorities, and regulations. In her theory of a "networked world order," Slaughter (2004, pp. 227-30, 245-47) emphasizes the novel ways in which states and political and bureaucratic elites are embedded within global arrangements for governance. The World Bank, the EU, and NATO demonstrate how national decision-makers now cooperate with each other in interdependent arrangements for global governance. Yet 19th-century international unions differed from global networks, for private corporations were explicitly refused admission.

In addition to examining how 19th-century international unions constitute a "prehistory" of global governance, this essay challenges the conclusions of a type of research on the ISC, which places the ISC in one or another teleological argument: the progress of medical knowledge and scientific certainty (Howard-Jones, 1950; WHO, 1958); the progressive growth of internationalism or international consciousness (WHO, 1958; Harrison, 2006); or the advance of international and now global health arrangements (Fidler, 2004; Mbengue, 2011; McInnes \& Lee, 2012, pp. 104-106, 133-37). Instead, this essay gives more credence to the work of Stefan Elbe (2010, pp. 58-61), who argues that practices such as quarantine come and go with no reliable scientific basis, from cholera in the nineteenth century to HIV or SARS in recent decades; and to that of Valeska Huber (2006, pp. 459-61), who sees the ISC as a Eurocentric internationalism especially concerned with national economic goals and scientific expertise. I quite agree with her judgment that, ultimately, the ISC assisted with the policing of the international movement of people (Huber, 2006, pp. 471-76).

At the same time, this essay contributes to recent analyses of territorialization in the nineteenth century, as nations and states began to emphasize possession, control, and sovereignty. The larger project of which this essay is a part explores the territorialization of state sovereignty in the nineteenth century. Here, questions of cholera quarantine engage political behavior (for want of a better term) that, in the second half of the nineteenth century, looks like what we would call state sovereignty today, but that is because such practices have been taken up by and are now comfortably attributed to states. Rather, the territorial negotiations surrounding cholera quarantine are often based in colonial or extraterritorial agreements that are an effect of power, but these acts of power are subsequently presented as legal arrangements. The primary reason that cholera quarantine defies attributes of "state sovereignty" is because interested parties tended to commit themselves to decisions made at the local level—whether state, national, or port authorities. Ultimately, as we will see, the ship captain would be made responsible for port security. Hence it especially makes sense to describe these processes as transnational.

This essay proceeds as follows: we look first at the Ottoman sanitary boards and the meetings of the ISC. We look specifically at the 1881 meeting in Washington, which demonstrates that not faulty medical knowledge but the defense of national territory accounts for the "failure" of the ISC up to 1892. Finally, we look at the developments of 1892 and 1894, when Europeans finally cooperated to manage the Suez Canal and the Red Sea, and to police the ships transporting pilgrims to Mecca. Although concern over the spread of cholera continued to inform European worries about quarantine, the 1892 and 1894 Conventions succeeded because they were impositions upon the weakened 
Ottoman Empire and the non-Europeans who inhabited and passed through Ottoman territory. The Conventions were, in this regard, chauvinistic yet strikingly innovative in that they treated the movement of Muslims in terms of its commercial basis - the business of transporting pilgrims to Mecca as ship passengers.

\section{Ottoman Capitulations and Quarantine Boards}

The institution of the Ottoman quarantine boards, established in the 1830s, was a precedent for the work of the ISC: it represented a first effort to create a single quarantine system for Ottoman lands and, according to Mark Harrison (2006, pp. 204, 211), the creation of a sanitary board in 1831 by Muhammed Ali, Khedive of Egypt, was the first indication that international cooperation on quarantine might be possible.

Three quarantine boards were established in the 1830s: Alexandria in 1831, Constantinople (Istanbul) in 1838, and Tangier in $1840 .{ }^{2}$ The first two at Alexandria and Constantinople remained the key stations for the duration of the century. From the start, they faced pressure from the European powers, for they were integrated into the fabric of Ottoman capitulations and operated under those conditions of extraterritoriality. The foreign powers with representatives in Istanbul immediately protested the Sultan's quarantine regulations of 1838; they argued that the capitulation agreements with European heads of state had prescribed a fixed set of taxes, and quarantine was deemed an extra sanitation tax and thus not allowed. The foreign representatives thus pressured the Sultan's government to renegotiate the law, with the result that a joint authority was established in 1839 - an international medical board which operated largely under Ottoman and French medical oversight for the next few decades. According to Paul Faivre (1908, pp. 56-58), the Ottoman government appointed seven of the board of twelve members, and the remaining five constituted a foreign delegation. But as newer states established relations with the Ottomans - the USA and Persia, for example - the foreign contingent grew larger. Schepin and Yermakov (1991, pp. 52-57) argue that the Ottoman Porte came to regard the international domination of the board in Constantinople as a violation of its sovereignty, even though Europeans opposed to quarantine tended to complain that the council always voted for the Ottoman position - in favor of quarantine. This is perhaps because, as we will see in the context of the ISC, quarantine was always the failsafe remedy in the face of an epidemic.

Similarly, the board in Alexandria was reportedly mired in disputes between Egyptian authorities and the foreign consuls until the 1851 meeting of the ISC provided some stability, because debate over quarantine was removed from Alexandria to the international settings of the ISCs. Despite Egypt's membership in the ISC, the attention of the ISC meant that European interests dominated the quarantine station in Alexandria. Britain's conquest of Egypt in 1881 coincided with the Khedivial decree of 1881 which reorganized the Alexandria quarantine board as the "Conseil Sanitaire, Maritime, et Quarantenaire d'Égypte" and it was this Council that the ISC formally certified as an international organization in 1892, when it finally managed to sign and to ratify an agreement - a point to which we return. (Faivre, 1908, pp. 61-65; Schepin \& Yermakov, 1991, pp. 47-49; see also Howard-Jones, 1975, p. 63; Lyons, 1963, pp. 240f., 243; Mangone, 1954, p. 80f.; WHO, 1958, pp. 32-34.) Two points are clear from this brief description of Ottoman quarantine institutions: First, Britain took the lead in European interference in Ottoman quarantine law and the European demand for cooperation over quarantine policy. Second, European treatment of the Ottomans served as a precedent for European practice elsewhere in the world: Japan, for example, was the exact contemporary of the Ottomans insofar as both were targets of a growing European imperialism-not so much in terms of European chauvinistic attitudes toward "Asians" but in the sense that cholera quarantine became a colonial practice by century's end.

\section{The Inconclusive Work of the International Sanitary Conference (ISC)}

Longstanding scientific and political controversies undermined the success of the ISC between 1851 and 1892 . Trade was the ultimate reason for the initiation of the ISC in 1851. Because quarantine regulations differed from port to port, the uncertainties and costly dislocations that cholera quarantines posed to trade were the reasons given in mid-century for a meeting of Mediterranean trading partners and port authorities. Their goal was to work out a common strategy of quarantine in order to streamline trade in the face of potential epidemics. The main problem, as the century developed, was the accelerating speed at which diseases could be transmitted-from sailing ships to steam-driven ships to railroads - and the growth of industrialization which produced the squalid and overcrowded urban conditions in which cholera found a foothold. Linking these two developments was the expansion of colonialism and its interests in trade, efficiency, and the free circulation of labor (Cooper, 1989, p. 203f.; Harrison, 2006, pp. 213-15; Huber, 2006, p. 454f.; Porter, 1999, pp. 79-96; Schepin \& Yermakov, 1991, p. 95f.; WHO, 1958, p. 3). Of special interest to us are the

\footnotetext{
${ }^{2}$ A fourth quarantine board was established in Teheran in 1867. Accounts of the Ottoman quarantine boards are available in Faivre (1908, pp. 55-71); Goodman (1971, pp. 318-26); and Schepin and Yermakov (1991, pp. 45-62). It is anachronistic that western sources insist upon "Constantinople" rather than the proper name for the city, "Istanbul," and occasionally refer to "Turkey" rather than what was properly the Ottoman Porte.
} 
transnational controversies that dominated the ISC in its first four decades: first, the inability of the international scientific and medical community to agree upon the etiology and epidemiology of cholera; and second, the inability of the international diplomatic community to agree on a common set of procedures in response to the threat of transnational diseases.

\subsection{The Fitful Science of Cholera}

The primary problem during the second half of the nineteenth century was the serious disagreement among medical and scientific delegates to the ISC over the etiology and epidemiology of cholera. This was especially acute because, in the absence of any ratified agreement within the ISC, the organization typically disbanded until a renewed epidemic reminded members that something might be done to coordinate their responses to the threat of disease. Hence, meetings of the ISC typically included a review of the state of medical science.

Two related controversies divided scientists in the nineteenth century: the dispute between anti-contagionists and contagionists; and the growth of sanitation or hygiene as an alternative to the medical research of disease. To put it simply, the anti-contagionists were unconvinced that cholera was contagious and believed instead that it was spread through some miasma in the environment. The debate was given new life at the 1866 conference in Constantinople, where Max von Pettenkofer of Bavaria announced a new "scientific" theory of the spread of cholera. His "topographical" theory argued that cholera was spread not through water but through soil that contained excrement and specifically affected individuals who were susceptible to the disease. (Howard-Jones, 1975, pp. 23-27, 35-37, 46; WHO, 1958, pp. 9, 11f.; Cooper, 1989, pp. 200-203) The tenacity of Pettenkofer's theory is remarkable for its utter ignorance of other scientific developments. Filippo Pacini in Italy and John Snow in England had already made discoveries about cholera that went entirely unnoticed. Pacini identified the cholera vibrio as the disease pathogen and publicized his discovery in an 1854 paper; unfortunately, because he wrote in Italian, it went unread. Snow, in a book published in 1855, demonstrated the contagiousness of cholera with his analysis of the spread of cholera in London in 1854, through contaminated drinking water (Howard-Jones, 1975, pp. 17, 43f.; Cooper, 1989, pp. 197-99; WHO, 1958, p. 9). Yet Pettenkofer's work continued to dominate ISC meetings, even after Robert Koch (re)identified the cholera pathogen in 1883. Two major cholera conferences in Berlin, in 1884 and 1885, could not overrule Pettenkofer, and only in the wake of the 1892 epidemic in Hamburg did a majority of scientists begin to accept Koch's argument (Coleman, 1987; Evans, 1987, pp. 226-56; Ogawa, 2000). Nonetheless, doubt persisted at the 1892, 1893, and 1894 meetings of the ISC, and it was not until after 1900, after researchers identified the transmission of yellow fever by mosquitoes and the plague bacillus by rats, that the existence of the cholera vibrio was accepted (Howard-Jones, 1975, pp. 48-54, 74-77, 89-92; Cooper, 1989, pp. 217-26; Fidler, 1999, pp. 35-42; Schepin \& Yermakov, 1991, pp. 112-16; WHO, 1958, pp. 13-16).

Science, in other words, was not the progressive force of knowledge as it is so often portrayed. Bruno Latour (1988, pp. 19-34) has emphasized, in his discussion of the integration of hygiene into the debates over the causes of disease, that the anti-contagion concept of "morbid spontaneity" produced a plethora of causes, examples, and counter-examples: "[T]he fundamental problem of the hygienists is that this multiplicity, so short on remedies and details, did not protect them against failure. However much they might take precautions against everything and observe everywhere, disease returned, as if no fixed causes could be attributed to it" (p. 21). As Anne Rasmussen has shown (2001), the fact that the ISC meetings proceeded in tandem with rival international hygiene congresses not only multiplied the opportunities for confusion over the competence of scientific knowledge and hygienic practices, but also undercut international solidarity.

Why, then, did the ISC stick with erroneous medical information for half a century? A repeated explanation is that the dominant commercial interests supported anti-contagionism and undertook to overrule both quarantine and contagion theory. In the absence of a more effective way to combat disease, the contagionists relied on the traditional method of quarantine, while the anti-contagionists, led by the British, turned to the inspection of ships and improvements in sanitation. What is most astonishing in the nineteenth-century battle with cholera is that the erroneous theory of anti-contagionism suppressed the alternative yet correct hypothesis of contagionism, but the erroneous theory nonetheless demonstrated a more effective response to the disease. The British approach to cholera proved to be the right thing to do: inspection, disinfection, and isolation of the infected (Cooper, 1989, pp. 245, 249; Howard-Jones, 1950, p. 1034).

\subsection{The National Approach to Procedures}

In other words, the presence or absence of sound medical knowledge offered little guidance for the international policy regarding cholera that the ISC was attempting to forge. During the second half of the century, there was always the perception that quarantine as a remedy was arguably as bad as the disease, in that economic dislocation and panic ensued when cholera was announced and ships or ports were placed under quarantine. The British solution - formalized in Britain's Cholera Regulations of 1883 - was to keep ports open and, at the same time, to institute a system to inspect 
suspect ships, to disinfect them, and to remove all infected persons to specially provided hospitals (Goodman, 1971, pp. 36-42; Cooper, 1989, pp. 190-93; Hardy, 1993; Howard-Jones, 1950, p. 1033f.; Howard-Jones, 1975, p. 56f.; Schepin \& Yermakov, 1991, pp. 74f., 82-85). Because the ISCs tended to be called in the wake of yet another epidemic of cholera or plague, there was pressure on states to quarantine, even if the anti-contagionists argued against quarantine. What generally happened was that, in the absence of unanimity, ISC members acknowledged that port authorities could undertake any measures of precaution at their discretion in case of immediate threat. In 1866, and again in 1874 and 1885, the ISC recognized three courses of action: sanitation; a short quarantine of observation; and a rigorous quarantine of several days. That is, both sanitation and quarantine were approved, if begrudged, plans of action (Schepin \& Yermakov, 1991, pp. 88f., 101, 121). The one "scientific" judgment that impacted quarantine regulations in the century was the acknowledgement by medical delegates to the ISC that researchers had identified a five- to six-day incubation period for cholera, and recommended that quarantine detention be reduced to seven days (Schepin \& Yermakov, 1991, p. 102). ${ }^{3}$

National rivalries frustrated the process of ISC agreement. With most of the shipping through the Suez Canal and the Mediterranean in British hands, Britain tended to dominate port authorities and their responses to cholera. British policy tended to grant local authorities the right to do what they wanted to do, but in addition, Britain signed bilateral agreements with some states to allow British ships free passage and, after 1881, simply granted British ships free passage through the Suez Canal (Schepin \& Yermakov, 1991, p. 76f.). There was a modest rebellion against this practice at the Rome meeting of the ISC in 1885, as a majority of delegates protested against this British policy at Suez, but they nonetheless recognized that Britain dominated international practices anyway, and this helps to explain why, until 1892, quarantine matters tended to be left up to each country or port (Howard-Jones, 1975, p. 56). Hence, we are left with the following conundrum within the ISC: On the one hand, the British remained interested in a collective approach to epidemic diseases, both because of British interest in commercial efficiency and because both quarantine and the British method of supervision and isolation depended on prompt and early notification that cholera was on the way (Lyons, 1963, p. 239). On the other hand, as David Fidler has noted (1999, p. 32), the British approach indicated that control of infectious diseases called for national action on sanitation and public health reform rather than international cooperation on quarantine. And that, in fact, remained the norm in the nineteenth century: nations and port authorities established their own policies. In spite of their suspect medical knowledge and uncertain theory of disease, these remained the agents of quarantine, and no international agreement could be reached on what was an obviously transnational problem.

\section{The 1881 ISC in Washington: Claims of Territorial Sovereignty}

The 1881 meeting of the ISC in Washington broke with the pattern of the earlier meetings in striking ways: for the first and only time, it was held outside of Europe and, for that reason, included many states from Asia and Latin America. Like the 1859 meeting in Paris, there was no discussion in 1881 of the medical science of disease. Rather, the issues proved to be primarily political, and hence the 1881 meeting especially confirms my argument that the politics of sovereign claims dominated quarantine measures and undercut transnational cooperation.

The official invitation from the US Department of State outlined the rationale for the conference: The USA faced two main problems with current practices of quarantine: local authorities in foreign ports were uncooperative with US consular and medical authorities in carrying out regulations that the USA deemed necessary as a sanitary safeguard; and vague or untrustworthy evidence was often all that was available regarding vessels coming to the USA. The USA recognized that quarantine is an essentially local set of requirements and must be adapted to the sanitary conditions where it is applied; hence, the USA believed that an international code of quarantine was inappropriate, for local conditions varied widely. Accordingly, the USA had determined that the best path to pursue was an international notification system, and it invited the ISC to Washington in order to discuss the best means of certifying vessels and/or ports and the best way to obtain and to circulate trustworthy information about the presence of disease (ISC, 1881, pp. 158-60).

But the State Department memo proposed a legal development that would undermine solidarity at the conference. Having embraced the sanitation movement in the 1870s, the US Federal government created a US Health Department in 1878 and passed a new law in June 1879 that required the certification of the health of a ship sailing to the USA prior to its departure. In order to bypass uncooperative or unknowledgeable local authorities, the USA proposed that the US consul in the foreign port would perform the certification (“An act to prevent ..." [1879]; ISC, 1881, pp. 161-64; see also Howard-Jones, 1975, p. 43; Goodman, 1971, p. 61f.; Cooper, 1989, pp. 206-208; Schepin \& Yermakov, 1991, p. 106). Such an action of course depended on the cooperation of foreign states, and one of the reasons for which the USA had called the ISC to Washington was to induce support for this practice as an international norm. (ISC, 1881, pp. 16, 54.)

\footnotetext{
${ }^{3}$ Latour (1988, p. 43) argues that, by 1885 , scientists had determined that cholera had a five-day incubation period, so quarantine could be safely reduced to six days. But the 1892 ISC continued to prescribe a quarantine of seven days.
} 
It was not such an outlandish idea. Sherston Baker, an English authority on international laws of quarantine, had proposed such a plan before the meeting of the International Law Association in London in August 1879. In proposing his "International Rules of Quarantine," Baker (1880) noted the continuing lack of agreement and ratification of the work of the ISC, and very much reiterated the reasoning of the USA. In the absence of world uniformity with quarantine regulations, it might be more amenable to all states to issue an "international bill of health" to each vessel at its port of departure by the consul of the vessel's ultimate port of destination. At each port where the vessel touched, a new bill of health would be issued by the local authority and, again, the consul representing the port of final destination. These periodic inspections of each vessel would trigger recommended periods of quarantine, if cholera were detected. But quite in keeping with the status quo, Baker reassured his audience that each state would preserve its own quarantine system. $^{4}$

In Washington, however, the USA proposal drew more opposition than support. Although several countries welcomed the idea - Italy, Mexico, Portugal, and Venezuela - they were not convinced that a foreign power needed to make such a certification. On the one hand, Spain, Portugal, Mexico and Italy were confident that they themselves did their work conscientiously and reliably; on the other hand, Portugal's Viscount das Nogueiras noted the lack of uniformity in the world, which would surely constitute an impediment to solidarity. Accordingly, as Venezuela's Simon Camacho and the Netherlands' F.J. van Leent argued, the situation required that each member state formally commit itself to the national maintenance of certain sanitary requirements. Otherwise, Spain's Rafael Cervera insisted, the reciprocity which the USA proposed, in consideration for the powers granted to foreign agents in one's own ports, would become problematic. A country such as Spain with a perfectly functioning national sanitary organization could expect nothing comparable from another country with no central sanitary organization or an inferior one at best (ISC, 1881, pp. 19f., 32f., 78f.). As it was, both the USA and Canada lacked national organizations for quarantine, leaving the matter to local port authorities.

In its defense, US delegate James Cabell pointed out that these arrangements were already practiced in many parts of the world. He cited the French cooperation with Turkey in creating a joint surveillance group in Turkey and Egypt which issued bills of health for vessels departing therefrom. He noted that the USA had not invented such laws; rather, the USA had modeled its 1879 law after many such national laws that required vessels bound for their shores to be certified at the port of departure, including Portugal's "Regulations for Maritime Health" of 1874 and similar laws of Italy, Austria, and Great Britain. Cuba and the USA had already signed such an arrangement, which was proving effective in the fight against yellow fever (ISC, 1881, pp. 50-55).

But practical concerns with the radical departure from the status quo forced a change in the US proposal. As France's Maxime Outrey cautioned, empowering a foreign consul to certify the health of ships in a foreign port was an extraordinary change to current diplomatic procedures - a point which the USA acknowledged (ISC, 1881, pp. 20, 76). To begin with, consuls had neither such official authorization at present nor such expertise. Even the idea that a consul would work with his medical officer in making such judgments was problematic, for not all countries had a sufficient number of consuls in foreign ports, let alone medical officers; and it was perhaps not such a good idea to make a consul officially responsible for a decision reached by a medical counterpart (ISC, 1881, pp. 53, 70-73, 102). Moreover, as Spain's Cervera emphasized, the ISC had a duty to protect "the sovereignty of the different nations and their laws" (ISC, 1881, p. 31). In Cervera's prescient analysis, "national sovereignty" was infringed if a sanitary authority from country A were in a position to reject bills of health issued by an officer of another country B unless they were corroborated by an official from A stationed in that country B. Hence, the compromise resolution proposed by Italy was passed: local authorities at ports of departure would issue bills of health, and consuls of the countries of destination could endorse the correctness of the information therein (ISC, 1881, pp. 75, 148; Schepin \& Yermakov, 1991, pp. 108-10).

According to US delegates, the main concern was that US officers in both foreign and domestic ports have access to trustworthy information (ISC, 1881, p. 76). Hence the second USA proposal was to some degree more important than the first - the creation of an international health office to publicize information about the presence and potential spread of disease. The matter had been raised before at the 1851 and 1874 meetings, and some countries still blanched at the prospect that it would become difficult to conceal obvious insanitary conditions at their ports. In 1881, the new USA proposal advocated two international offices: one in Havana for the Americas (the site of Spain's infectious diseases hospital for yellow fever) and one in Vienna for Europe, Asia, and Africa (ISC, 1881, pp. 126-32; see also Mangone, 1954, p. 80; Howard-Jones, 1950, p. 1035; Howard-Jones, 1975, p. 42-45; Goodman, 1971, pp. 60-64; Schepin \& Yermakov, 1991, p. 102). But in coordination with an international office, the USA wanted each government to create its own national service that would be able to report upon the current state of public health to its citizens, and then to the

${ }^{4}$ See Baker, 1880, pp. 177-86. Baker's Laws of Quarantine (London, 1879) was cited at the 1881 ISC; see ISC, 1881, p. $52 \mathrm{f}$. 
international monitoring and reporting agency (Faivre, 1908, p. 18; ISC, 1881, p. 147). The problem with the proposal, again, concerned the practical matter of uniform standards of information gathering and reporting, and the questions of how often, by whom, and to whom information would be reported (ISC, 1881, pp. 40, 120-26). Because this discussion began late in the conference, delegates quickly compromised: reports would be issued by the chief medical officer of each nation, at no fixed schedule, to the appropriate center in either Vienna or Havana.

Yet some participants wanted to go further. To begin to forge a standard practice, Spain and other members proposed the creation of an international sanitary commission to conduct an international investigation of yellow fever and cholera (ISC, 1881, pp. 111-17, 151-54). They raised the possibility of a third international office in Asia (ISC, 1881, p. 127f.). Belgium's Eduard Sève argued in favor of an international organization with an administrative center, in the manner of the International Telegraph Union or the Universal Postal Union. To that end, he provided an "Essay on the General Organisation of Public Hygiene" which reviewed each nation's state of international medical preparedness (ISC, 1881, pp. 140, 167-77).

Like their predecessors, the "Final Act" that the 1881 meeting produced and circulated was laudatory and forward-looking, and began to alter the procedures of some member states, but it was never ratified as a treaty and so had no force as administrative law. Although some of the Latin American states returned to the ISC meeting in Rome four years later, they realized that they would do better to work amongst themselves and to forge some agreement for the Americas; a Pan-American Sanitary Bureau was eventually organized in 1902. Likewise, Japan attended the 1885 meeting in Rome but then ceased its involvement. Facing extraterritorial pressures from Britain and Germany, the Japanese Foreign Ministry was especially interested that the ISC had acknowledged the right of each state government to make its own rules regarding sanitation procedures (Howland, 2016, pp. 89-92). Japan would henceforth concentrate on its national sanitation system and eventually turn its attention to a collaborative project with the USA-the establishment in 1907 of a permanent international commission for "epidemics in the far east" (Paillette, 2012, p. 243).

\section{Quarantine and Chauvinism}

The 1881 ISC could not overcome the grounding of sanitation policy and quarantine law in the right of a national government to make law for its own territory. Accordingly, the "successes" of the ISC in the 1890s are especially revealing, for the ISC proved remarkably complicit with the chauvinism of imperialism in the two International Sanitary Conventions signed in 1892 and 1894. These were surveillance and quarantine agreements, the first reached with Egyptian authorities and the second imposed on Ottoman authorities. To begin with, the 1892 agreement formalized the Egyptian Khedive's sanitary office as an international organization under the cooperation of Egyptian and foreign officials. The 1892 convention is remarkable for its regulation of everything in minute detail-procedures of inspection, hospitalization of the sick and, if necessary, quarantine. After forty years of discussions, the European powers finally created an agreement based on their collective concerns over passage through the Suez Canal, two details of which stand out. First, the authority empowered to administer the regulations of the Convention was the Khedive's Conseil, which the ISC restructured so that only four members were appointed by Egypt; as a point of international administrative law, the Conseil was dominated by the foreign members ("International Sanitary Convention," 1892, pp. 405-407). Second, because Egypt at the 1892 ISC meeting was loudly unwilling to supervise quarantine-it had no funding or facilities to house, say, 1500 persons from a large ship or two-the 1892 Convention allowed that the financing of the prescribed facilities (particularly hospitals and disinfection stations) might be borrowed from the lighthouse commission or derived from a new sanitation tax, levied either on each passenger through Suez (excluding military personnel or pilgrims to Mecca) or according to a rate based on the tonnage of ships moving through Suez (Howard-Jones, 1975, p. 64; Huber, 2006, p. 468; "International Sanitary Convention,” 1892, p. 404f.). The 1892 Convention also enlisted the international telegraph network for speedier notifications: an infected ship was required to communicate by telegram with its national consul in its next port-of-call and to port sanitation authorities - the ship of course paid the telegraph costs for these mandatory communiqués ("International Sanitary Convention," 1892, pp. 403, 420; see also Howard-Jones, 1975, p. 63; Biraud, 1950, p. 1046f.). From 1892 until the second World War, according to Neville Goodman (1971, p. 320), the Alexandria Conseil provided effective health administration for Alexandria and the Suez Canal; as it developed from the 1894 Convention, its main task was to police the pilgrims travelling to Mecca, and its funding was eventually derived from a tax on those pilgrims and ships, with additional grants from the Government of Egypt.

A second "success" of the ISC of the 1890s, complicit with European imperialism insofar as it was imposed upon a weakened Ottoman government, was the solution finally reached with the international bill of health issued to ships in port. The 1894 "International Sanitary Convention," the object of which was to police the movement of pilgrims to Mecca and to create a standard quarantine regulation especially for the Red Sea, was the occasion for revisiting the issues that had occupied the ISC in 1881. Like its predecessor in 1892, this 1894 Convention is somewhat astonishing in that forty-some years of discussions over sanitation, quarantine, and medical science resulted in an agreement to police 
Muslims travelling to Mecca. As regards the prevention of disease, the standards of the 1894 regulations returned to the guidelines of 1874: inspection of ships, a one-day quarantine if no disease on board had been reported, a seven-day quarantine if disease had been reported, and the removal of the sick to a quarantine hospital.

What is novel and striking in the 1894 Convention is a seismic change in the mechanism of information and reporting. This discussion, recall, was terminated in 1881 in favor of the local health official, who would issue an international bill of health to a vessel, and the consul of the vessel's port of final destination might countersign. In 1894, the ship captain became part of the solution, as the ship became the site of surveillance.

As was becoming the international norm at the time, a ship was considered national territory when on the high seas and the captain of the ship had authority over all persons on the ship, regardless of their nationality. For the duration of the voyage, all on board were subject to the laws of the nation of the ship. When in port, the ship and all on board were subject to the local authorities and their laws. But extraterritoriality in East Asia and elsewhere introduced a new problem: a British ship may dock in Chinese or Japanese waters, for example, but extraterritoriality removed the ship from Chinese or Japanese jurisdiction. Hence, the solution reached in the $1880 \mathrm{~s}$ was that, under conditions of extraterritoriality in a port of China or Japan, a foreign ship would be "as if" on the high seas, under the authority of the captain and the laws of the nationality of the ship (Howland, 2009).

The 1894 "International Sanitary Convention" refocused the place of the ship in surveillance and quarantine regulations. Where the 1892 Convention made the ship a unit of taxation in order to support the work of the port authorities, the 1894 "International Sanitary Convention" put the ship at the center of surveillance for disease. There were three sites at issue in quarantine: the port of departure where disease could infect a ship; the ship that may unsuspectingly be carrying disease; and the port of arrival, which wanted to avoid infection. The 1881 ISC gave precedence to the port of arrival and, in attempting to prevent the introduction of disease therein, proposed to insert the sovereignty of that territory into the port of departure. This was perhaps a reasonable measure in order to protect the port of arrival, but it was also an infringement of the sovereignty of the port of departure that a majority of members refused to condone. Hence the 1894 Convention made the ship the object of surveillance, which recast the problem of sovereignty into one of ships as national territory and private property. The ship captain —or, in his absence, the owner of the vessel or his agent—was responsible for the international bill of health. It was the captain's duty to secure from the competent local authority both the bill of health and permission to depart. The local authority must inspect the ship and, in a variation of what we have seen in the 1881 ISC, the consul of the owner of the ship may assist with that inspection ("International Sanitary Convention," 1894, pp. 108-10). The principle of property in the ship has replaced the port of destination in a substitution of national territory. And the sovereignty of national territory remains firmly in place: local port authorities stand on their national sovereignty, and the vessel is property recognized under the law of another national territory. Now, however, authorities at the port of arrival can act with better information, because the ship captain is obliged to communicate by telegraph, and the ship captain and its owners suffer the consequences of the disease that they may carry. To assist this process of surveillance, the 1894 Convention established a comprehensive "sanitation regime" in the Red Sea and Persian Gulf, with a series of sanitation stations for the inspection of ships and pilgrims ("International Sanitary Convention," 1894, pp. 115-22).

\section{Conclusions}

Although the 1892 and 1894 Conventions represent a growing European imperialism, they were nonetheless path-breaking, not only because they marked an official shift from quarantine to surveillance as a primary tactic of combatting disease-quarantine was thereafter reserved for a last resort-but they also provided a precedent for European states to cooperate among each other for some collective approach to surveillance within Europe. A decade later, the 1903 ISC meeting in Paris produced the 1903 Convention that finally established an international organization for surveillance and notification: the Office International d'Hygiène Publique (OIHP), which opened in 1907 in Paris (Howard-Jones, 1975, pp. 86-88; Fidler, 1999, pp. 47-52; Schmeckebier, 1935, pp. 205-15; WHO, 1958, pp. 16-21). Although the OIHP pursued surveillance and publicized outbreaks of disease, it had no authority to command member states to undertake certain actions. Rather, it made recommendations that governments might institute and, in that regard, it protected what was becoming called the territorial sovereignty of member states (Schmeckebier, 1935, p. 204; Mbengue, 2011; Fidler, 1999, p. 51f.).

Because of this persistent limiting of international cooperation in the name of national sovereignty, this essay reaches different conclusions from those scholars who write on the history of the ISC within the context of public health. Scholars such as Richard Cooper and David Fidler emphasize the economics of sanitation and health care-a perspective informed by recent fiscal concerns. In raising the question, "Why did international health cooperation take so long?," Cooper (1989, pp. 237-40) argues that costs were related to remedies, and remedies were related to causes, about which disagreement continued for most of the century. Many countries supported the longstanding technique of 
quarantine, but because Britain had come to believe that trade was more valuable than quarantine, Britain's focus on sanitation and the cleaning up of Britain's cities, sewage, and water supplies worked to decrease the incidence of cholera in Britain. In spite of the spread of this sanitation movement to France, the USA, and Prussia, this was an expensive approach to the problem and many countries simply couldn't afford it. So poorer countries favored the contagion theory with its policy implication of quarantine, which was less costly to them. Cooper concludes that cooperation on international health problems finally began in the twentieth century-at the point that therapeutic pharmaceuticals were available for nations to combat disease within their own territories. As in the nineteenth century, information was exchanged but decisions were left at the national level, and international agreements did little more than to attempt to coordinate national policies and actions (Cooper, 1989, p. 241; see also Fidler, 1999, pp. 11-13).

Fidler offers a similar analysis. His concept of microbialpolitik is meant to get at the international relations of pathogenic microbes as they began in the nineteenth century, with quarantine and the fear of epidemics in conflict with growing trade and economic power. To Fidler (1999, p. 19), microbialpolitik is a product of both the impact that infectious diseases have on international relations and the impact that the structure and dynamics of international relations has on infectious diseases and their control. As we have confirmed here, science was at odds with public health measures such as quarantine in the nineteenth century. But where Cooper emphasizes the break-through of pharmaceuticals, Fidler (1999, pp. 52-55) locates the shift somewhat later in the twentieth century, when the developed countries realized that international infectious diseases required assistance to less-developed countries and regions. In Fidler's analysis (1999, p. 56), the cost of hygiene and disease control is still a critical factor, but sovereignty was enough of a powerful attachment to states in the century from 1851 to 1951 that states limited what could be accomplished through international law and international organizations (cf. Mbengue, 2011, p. 4f.).

Fidler's trajectory of the advance of international public health cooperation locates a major break at the SARS epidemic of 2003 (2004, pp. 57-60), when private organizations and informal associations - outside of government control—blew the whistle on the spread of SARS. To Fidler (2004, pp. 60-68), the SARS epidemic ended the regime of International Health Regulations, which had guided international public health under the League of Nations and the United Nations, and necessitated the participation of NGOs and private groups. But recent research by Céline Paillette (2012) locates this alternate formation much earlier in the twentieth century. Paillettte's fine analysis of structural changes in the globalization of public health under the 1920s leadership of the League of Nations is striking. Owing largely to the unwillingness of France to let the headquarters of the OIHP leave Paris and that of the USA to join the League and allow the merging of the OIHP into League-sponsored organizations, the Health Organization of the League became a transnational hybrid of public and private agents, unprecedented as a global form. The Rockefeller Foundation in the USA teamed up with the International Red Cross and other groups to reorganize medical surveillance, notification, and sanitation assistance during the interwar years. That said, Paillette and Fidler agree that the creation of the WHO under the auspices of the UN in 1951 marked a break with the nineteenth-century approach inaugurated by the Ottoman sanitation boards and the ISC.

This essay, by contrast, has stressed instead the politics within the ISC. Rather than Cooper's concern with delays in international cooperation, I wonder why cholera quarantine and the ISC were so strikingly different from other international efforts in the nineteenth century. The International Telegraph Union, founded in 1865, and the Universal Postal Union, founded in 1874, quite readily established international agreements, international offices, and a regimen of periodic conferences to update and revise their procedures. Both of these unions accommodated national sovereignty to a degree, in that both the ITU and UPU permitted a member administration to hold telegrams or letters that it might deem a threat to national interests. In order to guarantee uniform practices within the legal regimes established by the ITU and UPU - as had been proposed at the 1881 meeting of the ISC - both organizations required members to create national legislation that would bring its telegraph or postal practices up to ITU and UPU standards.

That European states could not establish common quarantine procedures must be attributed to the close alliance of national trade and national territory against the risk from disease and under the banner of sovereignty. Britain provided the model and incentive: it established a national sanitation program as a national defense against disease and thus demanded freedom for its ships from quarantine, a demand that carried much weight because Britain dominated world trade. In the nineteenth century, as Huber has noted (2006, p. 466), each state might have the power to voice its interests within the ISC, but even greater power could be brought to bear by the state that simply refused to cooperate.

\section{Acknowledgments}

An earlier version of this paper was presented for the conference "Transnational Process and the Modern State: Changing Modes of Socio-Political Organization through Transnationalization," at Universität Trier, Germany, in April 2014. I would like to thank Friederike Kuntz, Maximilian Mayer, Maaike Voorhoeve, and Luise White for their comments on that draft. 


\section{References}

An act to prevent the introduction of contagious or infections diseases into the United States (1879). Statutes at Large of the United States of America, 21(1881), 5-7.

Baker, S. (1880). Quarantine. In International Law Association, Report of the Seventh Annual Conference Held at the Guildhall, London, 11-16 August, 1879, 170-186. London: Wm. Clowes \& Sons.

Biraud, Y. (1950). The International Control of Epidemics. British Medical Journal , 1(4661), 1046-1050. PMCID: PMC2037635

Bourdelais, P. (1988). Présentation. In Jean-Pierre Bardet et al., Peurs et terreurs face à la contagion: choléra, tuberculose, syphilis, XIXe-XXe siècles, Paris: Fayard, 17-41.

Coleman, W. (1987). Koch's Comma Bacillus: The First Year. Bulletin of the History of Medicine, 61, 315-342. PMID: 3311246

Cooper, R. N. (1989). International Cooperation in Public Health as a Prologue to Macroeconomic Cooperation. In Richard N. Cooper et al., Can Nations Agree? Issues in International Economic Cooperation, 178-255. Washington: Brookings Institution, 178-255.

Elbe, S. (2010). Security and Global Health. Cambridge: Polity Press.

Evans, R. J. (1987). Death in Hamburg: Society and Politics in the Cholera Years, 1830-1910. Oxford: Clarendon.

Faivre, P. (1908). Prophylaxie internationale et nationale. Paris: J-B. Baillière.

Fidler, D. (1999). International Law and Infectious Diseases. Oxford: Clarendon.

Fidler, D. (2004). SARS, Governance and the Globalization of Disease. Houndmills: Palgrave-Macmillan.

Goodman, N. M. (1971). International Health Organizations and their Work. 2d. ed. Edinburgh: Churchill Livingstone.

Hamlin, C. (2009). Cholera: The Biography. Oxford: Oxford University Press.

Hardy, A. (1993). Cholera, Quarantine, and the English Preventative System, 1850-1895. Medical History, 37, $250-269$. PMCID: PMC1036746

Harrison, M. (2006). Disease, Diplomacy, and International Commerce: The Origins of International Sanitary. Regulation in the Nineteenth Century, Journal of Global History, 1(2), 197-217. http://dx.doi.org/10.1017/S1740022806000131

Howard-Jones, N. (1950). Origins of International Health Work. British Medical Journal, 4661, 1032-1037. PMCID: PMC2037586

Howard-Jones, N. (1975). The Scientific Background of the International Sanitary Conferences, 1851-1938. Geneva: W.H.O.

Howland, D. (2009). The Foreign and the Sovereign: Extraterritoriality in East Asia. In Douglas Howland and Luise White (Eds.), The State of Sovereignty: Territories, Laws, Populations, 35-55. Bloomington: Indiana University Press., 35-55.

Howland, D. (2015). An Alternative Mode of International Order: The International Administrative Union in the Nineteenth Century, Review of International Studies, 41(1), 161-83.

Howland, D. (2016). International Law and Japanese Sovereignty: The Emerging Global Order in the $19^{\text {th }}$ Century. N.Y.: Palgrave Macmillan.

Huber, V. (2006). The Unification of the Globe by Disease? The International Sanitary Conferences on Cholera, 1851-1894. The Historical Journal, 49(2), 453-476. http://dx.doi.org/10.1017/S0018246X06005280

International Sanitary Conference. (1881). Proceedings of the International Sanitary Conference provided by joint resolution of the Senate and House of Representatives in the early part of 1881. Washington: G.P.O.

International Sanitary Convention . . . signed at Paris, 3 April, 1894. In Clive Parry (Ed.), The Consolidated Treaty Series, 180, 101-23. Dobbs Ferry, N.Y.: Oceana, 1969-1981.

International Sanitary Convention ... signed at Venice, 30 January 1892. In Clive Parry (Ed.), The Consolidated Treaty Series, 176, 395-422. Dobbs Ferry, N.Y.: Oceana, 1969-1981.

Kingsbury, B., Krisch, N., \& Stewart, R. B. (2005). The Emergence of Global Administrative Law, Law and Contemporary Problems, 68(3-4), 16-37. http://scholarship.law.duke.edu/lcp/vol68/iss3/2

Latour, B. (1988). The Pasteurization of France, trans. A. Sheridan and J. Law. Cambridge: Harvard University Press. 
Lyons, F. S. L. (1963). Internationalism in Europe, 1815-1914. Leyden: Sythoff.

Mangone, G. J. (1954). A Short History of International Organization. N.Y.: McGraw-Hill.

Martens, F. F. (1883-1887). Traité de droit international, trans. Albert Leo. Paris: Librairie Marescq ainé.

Mbengue, M. M. (2011). Public Health, International Cooperation. In Rüdiger Wolfrum (Ed.), Max Planck Encyclopedia of Public International Law. (OUP, 2008-), online edition [www.mpepil.com], March 2012.

McInnes, C., \& Lee, K. (2012). Global Health and International Relations. Cambridge: Polity Press.

McNeill, W. H. (1976). Plagues and People. Garden City, NJ: Anchor Press/Doubleday.

Ogawa, M. (2000). Uneasy Bedfellows: Science and Politics in the Refutation of Koch's Bacterial Theory of Cholera,. Bulletin of the History of Medicine, 74, 671-707. http://dx.doi.org/10.1353/bhm.2000.0193

Paillette, C. (2012). Épidémies, santé et ordre mondial: Le rôle des organisations sanitaires internationales, 1903-1923, Monde(s): histoire, espaces, relations, 2, 237-56.

Pollitzer, R. (1954). Cholera Studies: 1. History of the Disease. Bulletin of the World Health Organization, 10, 421-61. PMCID: PMC2542143

Porter, D. (1999). Health, Civilization, and the State: A History of Public Health from Ancient to Modern Times. London: Routledge.

Rasmussen, A. (2001). L'hygiène en congrès (1852-1912): circulation et configurations internationales. In Patrice Bourdelais (Ed.), Les hygiénistes: enjeux, modèles et pratiques, XVIIIe - XXe siècle, 213-239. Paris: Belin, 213-239

Schepin, O. P., \& Yermakov, W. V. (1991). International Quarantine, trans. B. Meerovich and V. Bobrov. Madison: International Universities Press.

Schmeckebier, L. F. (1935). International Organizations in which the United States Participates. Washington: Brookings Institution.

Slaughter, A. (2004). A New World Order. Princeton: Princeton University Press.

WHO/World Health Organization. (1958). The First Ten Years of the World Health Organization. Geneva: W.H.O.

\section{(cc) $\mathrm{Br}$}

This work is licensed under a Creative Commons Attribution 3.0 License. 